\title{
Modelling dynamics of organic carbon in water hyacinth Eichhornia Crassipes (Mart.) Solms artificial wetlands
}

\author{
Aloyce W. Mayo \\ Department of Water Resources Engineering, University of Dar es Salaam, Tanzania. \\ Received 14 December, 2013; Accepted 10 April, 2014
}

\begin{abstract}
The role of water hyacinth on removal of organic carbon was investigated in free water constructed wetlands. A model incorporating the activities of suspended and biofilm biomasses was developed in order to simulate the various processes involved in the transformation and removal organic matter in the water hyacinths constructed wetland. The results show that the major processes governing the organic carbon transformation and removal in a water hyacinth constructed wetlands system are sedimentation of solids (56.5\%), regeneration of organic carbon $(25.5 \%)$, oxidation of organic carbon to carbon dioxide $(6.4 \%)$, plant decay $(4.4 \%)$ and uptake of organic carbon by heterotrophic bacteria (4.2\%). The total permanent removal of organic material was $26.7 \%$ of the total influent chemical oxygen demand (COD). The COD removal efficiency of the model when the effect of biofilm was considered was 40.5\%. However, in absence of biofilm activities, only $34.0 \%$ of COD was removed. This confirms the significance of the water hyacinth roots as an attachment media, which is extremely biologically active in assisting the organic carbon removal in the water hyacinth constructed wetland.
\end{abstract}

Key words: Water hyacinth, artificial wetlands, modelling, organic carbon.

\section{INTRODUCTION}

Water hyacinths have demonstrated a great potential for purification of wastewater through physical, chemical and biological mechanisms (Mayo and Kalibbala, 2007). Artificial wetlands have been used for secondary treatment (Gersberg et al., 1985; Vymazal, 2010) and for specific tertiary treatment such as removal of nitrogen (Senzia et al., 2004) and bacteria (Kalibbala et al., 2008; Mayo and Kalibbala, 2007; Vymazal, 2010). Successful case studies indicate that wetlands significantly reduce organic matter, suspended solids (SS), pathogens, heavy metals and excessive nutrients such as nitrogen, phosphorus and heavy metals from wastewater (Yi et al.,
2009; Mugasha, 1995; Mayo and Kalibbala, 2007; Mayo and Bigambo, 2005; Vymazal, 2010; Mayo et al., 2013). The deviation in chemical, biological, and physical characteristics among wetland ecosystems and complications in understanding and predicting the efficiency of such systems, have motivated the development of artificial wetland systems (Barrie, 2002). As a result, for over 50 years, natural and artificial wetlands have been engineered for wastewater treatment (Senzia, 2003) particularly for small and medium sized communities and isolated areas in Europe and the USA where over 700 artificial wetlands have been constructed

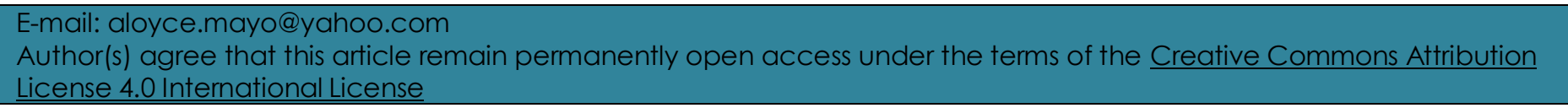


(Water 21, 2000).

Artificial wetland systems use floating or submerged aquatic plants in the treatment of industrial or domestic wastewater such as Eichhornia crassipes (Mayo and Kalibbala, 2007), Phragmites mauritianus (Senzia et al., 2004; Bigambo and Mayo, 2005) and Typha domingensis (Senzia, 2003; Nakibuule, 2013; Okurut, 2013). Until recently, most of the floating aquatic plant systems for wastewater treatment have been water hyacinth systems (USEPA, 1988). E. crassipes have been used in a variety of experimental and full-scale systems either for removing algae from oxidation pond effluents or for nutrient removal following secondary treatment in tropical regions (USEPA, 1988; Polprasert and Khatiwada, 1997). Other beneficial functions of wetlands include supplementary wildlife and human use benefits resulting from treatment wetlands. However, some researchers have also pointed potential problems of wastewater treatment in wetlands such as bioaccumulation of toxins and transmission of diseases (Knight et al., 2000; Muyodi, 2000).

Numerous studies have verified the usefulness of constructed wetlands (Barrie, 2002), and have provided a database for the development of design manuals for wastewater treatment with artificial wetlands (Reed et al., 1995). In spite of these advances on removal mechanisms of organic matter in constructed wetlands, models have failed to adequately predict performance of wetland systems. Organic carbon removal variability has tended to be influenced by a variety of factors resulting in its irregular removal pattern, which has complicated the optimization of organic carbon removal in artificial wetlands. The objectives of this paper are to determine and quantify the role of water hyacinth $E$. crassipes (Mart.) Solm for removal of organic carbon and to develop a mathematical model incorporating the activities of suspended biomass and bio-film on plant roots on removal rate of organic carbon in artificial water hyacinths wetland.

\section{METHODOLOGY}

\section{Layout of plant and data collection}

Two pilot wetland units of dimensions $7.5 \mathrm{~m}$ long, $3.5 \mathrm{~m}$ wide and $0.85 \mathrm{~m}$ deep were constructed adjacent to primary facultative pond at the University of Dar es Salaam (Figure 1). The location of the wetland units was at latitude $6^{\circ} 48^{\prime} \mathrm{S}$ and $39^{\circ} 13^{\prime} \mathrm{E}, 30 \mathrm{~m}$ to the north where the mean monthly air temperature of the site varies between 23 and $28^{\circ} \mathrm{C}$ with a mean value of $26^{\circ} \mathrm{C}$ (Mayo, 1989). The wetland units, which were planted with E. crassipes, were supplied with wastewater from the primary facultative pond at an average flow rate of 1000 L/day.

Flow was measured at the inlet and outlet of the water hyacinth unit with the aid of graduated container and a stopwatch. Samples of examination of water quality parameters were collected at the inlet and outlet of the system at 10:00 a.m once every two days. Samples were also collected along the length and depth of the wetland unit from sampling ports installed at the sides of the wetland units. Collections were done in a clean $250 \mathrm{ml}$ sampling bottles and samples were immediately taken to the water quality laboratory at the University of Dar es Salaam for examination. Samples containing settleable solids were blended with a homogenizer and preliminary dilutions were made for wastes containing high chemical oxygen demand (COD) to reduce the error in measuring small sample volumes. All physical-chemical parameters were determined in accordance to Standard Methods for the Examination of Water and Wastewater (1996). Analyses of samples were conducted within $2 \mathrm{~h}$ of sampling. Measurement of temperature and $\mathrm{pH}$ were done in-situ using $\mathrm{pH}$ meter (Metrohm $\mathrm{pH}$ meter, model 704). Dissolved oxygen (DO) concentrations were determined in-situ using a digital DO meter (YSI DO meter, model 50B). Chemical oxygen demand was measured using closed reflux method in accordance with Standard Methods for the Examination of Water and Wastewater (2012). Surfer 7.0 software was used to produce contour variation of the physical and chemical parameters with time, along the length and across the depth in the wetland unit.

\section{RESULTS}

\section{Variation of physical chemical parameters}

Concentration of dissolved oxygen (DO) in the wetland decreased from an average of $2.16 \mathrm{mg} / \mathrm{l}$ in the influent to $0.51 \mathrm{mg} / \mathrm{l}$ in the effluent. Dissolved oxygen decreased because the rate of its consumption by microorganisms for biodegradation of organic carbon was higher than its rate of production in the system. It is worth mentioning that water hyacinth plant roots generate only a small portion of the oxygen required for oxidation of organic carbon (Senzia, 2003). Unfortunately, interfacial diffusion of oxygen from the atmosphere and the production of oxygen by algae photosynthesis were suppressed by the dense plant cover, which reduced the surface gasexchange and wind-induced turbulence.

For similar reasons, the average $\mathrm{pH}$ in a water hyacinth wetland decreased from 7.87 to 7.26 because of complete cover provided by the plants on the water surface resulting in prevention light penetration, consequently inhibiting algae photosynthesis activities in the wetland. Consumption of $\mathrm{CO}_{2}$ decreased as a result of inhibition of growth of algae resulting in shift of Equation (1) towards the right. This has resulted in reduction of hydroxyl ions, thus lowering the $\mathrm{pH}$ of wastewater.

$$
\mathrm{CO}_{2}+\mathrm{OH}^{-} \Leftrightarrow \mathrm{HCO}_{3}^{-}
$$

The wetland system was $0.8^{\circ} \mathrm{C}$ colder at the effluent compared to the influent because of plant biomass mat, which prevented the direct solar energy from increasing the temperature of the wetland unit. This has a negative effect on the system as temperature has a significant influence on the rate of uptake of organic carbon, the interfacial gas transfer and settling rate of biological solids (Metcalf and Eddy, 1995).

Table 1 shows that COD concentration in the wetland 

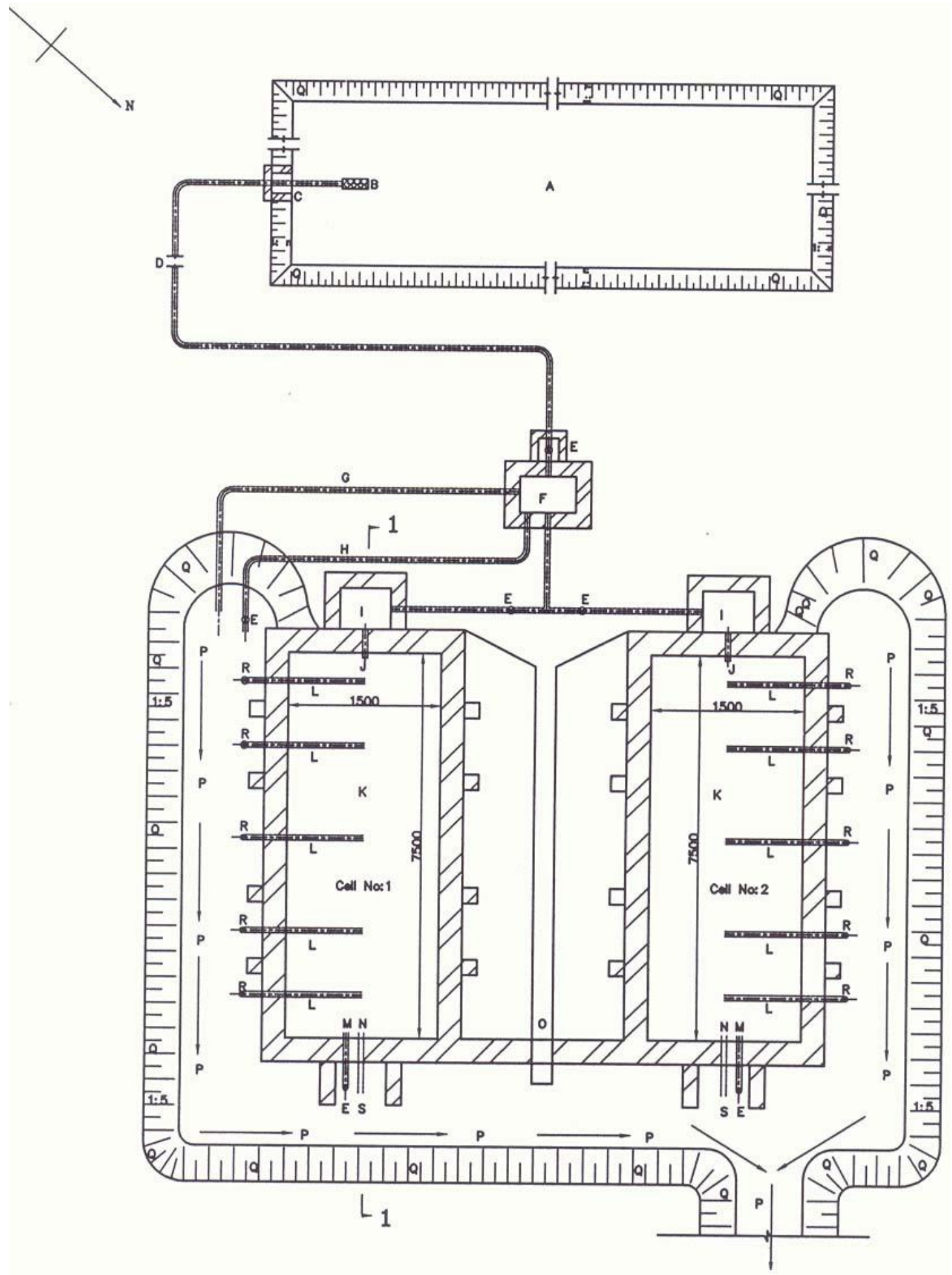

Figure 1. Layouts of the experimental wetland system.

decreased from an average of $210 \mathrm{mg} / \mathrm{l}$ in the influent to $121 \mathrm{mg} / \mathrm{l}$ in the effluent, which is equivalent to $42 \%$ removal efficiency. The variation of COD along the length and depth of the wetland unit shows that COD decreased from $215 \mathrm{mg} \mathrm{l}^{-1}$ near the influent to about $95 \mathrm{mg} \mathrm{l}^{-1}$ near the effluent (Figure 2). COD concentration decreased gradually along the length and appears to increase towards the bottom of the wetland unit. There was 
Table 1. Variation of physical-chemical parameters in water hyacinth wetland.

\begin{tabular}{llcccc}
\hline \multirow{2}{*}{ No } & \multirow{2}{*}{ Parameter } & \multicolumn{2}{c}{ Influent } & \multicolumn{2}{c}{ Effluent } \\
\cline { 2 - 5 } & & Range & Mean & Range & Mean \\
\hline 1. & pH & $7.75 \sim 8.14$ & 7.87 & $7.10 \sim 7.48$ & 7.26 \\
2. & Dissolved oxygen $(\mathrm{mg} / \mathrm{l})$ & $1.65 \sim 2.78$ & 2.16 & $0.36 \sim 0.68$ & 0.51 \\
3. & Temperature $\left({ }^{\circ} \mathrm{C}\right)$ & $26.5 \sim 27.7$ & 26.9 & $25.6 \sim 26.5$ & 26.1 \\
4. & Chemical oxygen demand $(\mathrm{mg} / \mathrm{l})$ & $184 \sim 228$ & 210 & $75 \sim 135$ & 121 \\
\hline
\end{tabular}
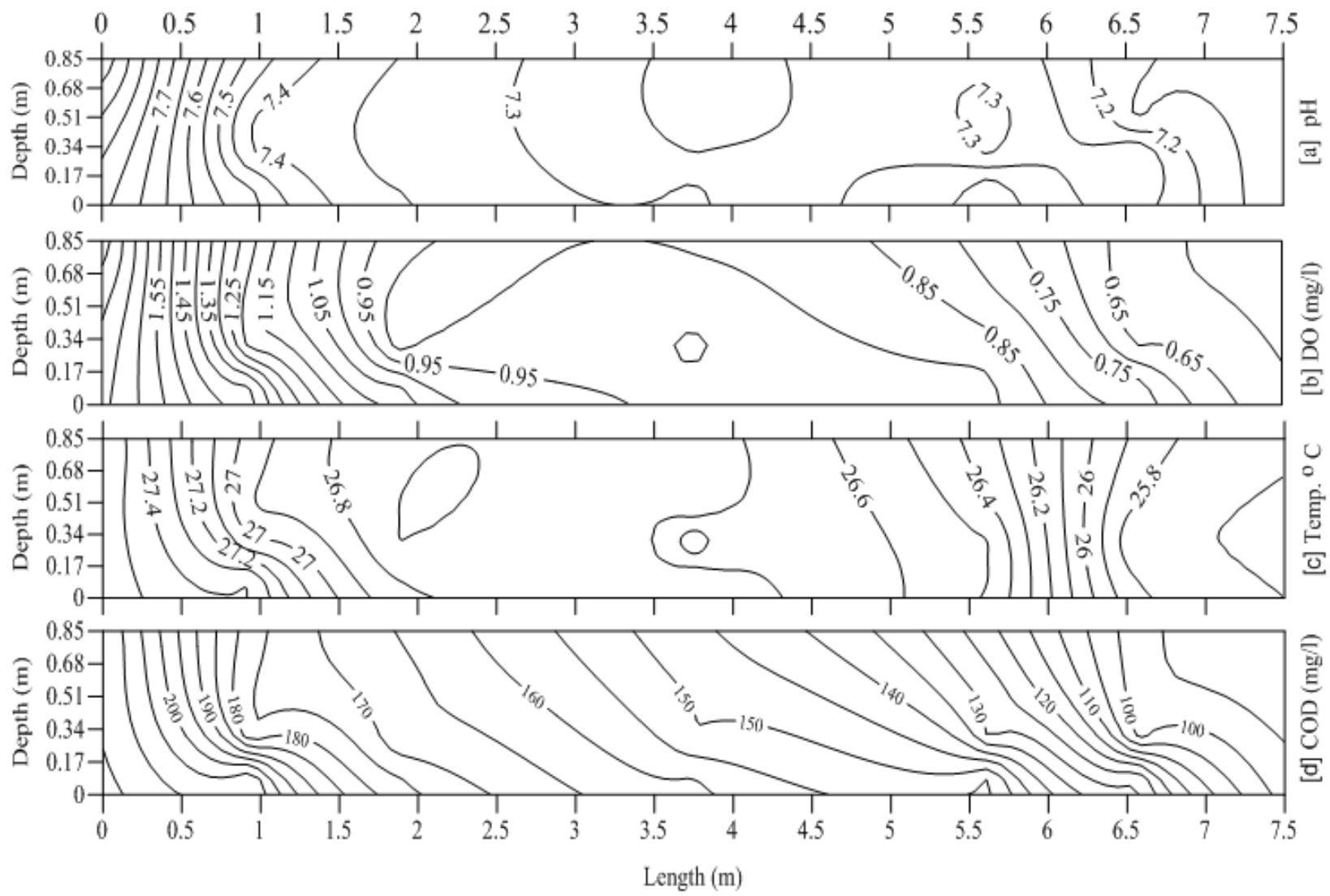

Figure 2. Variation of (a) $\mathrm{pH}$ (b) Dissolved oxygen (c) Temperature and (d) COD with the length and depth of the wetland.

evidence that COD was increasing with the depth of wetland unit, which is an indication of settling of organic particles to the benthic layer.

\section{Model development}

\section{Conceptual model and organic carbon mass balance}

The developed model incorporated activities of biofilm and suspended biomass on the transformation and removal mechanisms of organic carbon in the wetland unit. The model took into consideration the state variables substrate COD, COD in benthic layer and plant organic carbon as the major forms of organic carbon in the wetland unit. The transformation mechanisms that were considered in the model include oxidation of COD to carbon dioxide $\left(\mathrm{CO}_{2}\right)$, uptake of organic carbon by heterotrophic bacteria, regeneration of organic carbon, sedimentation of organic carbon, plant decay, generation of methane $\left(\mathrm{CH}_{4}\right)$ and release of carbon dioxide from the sediment. The transformation and removal mechanisms were conducted by attached root biofilm and suspended bacteria biomass.

The conceptual model that includes suspended and biofilm biomass activities influencing the organic carbon transformations and removal were developed (Figure 3). The model illustrates the material flow in and out of the 


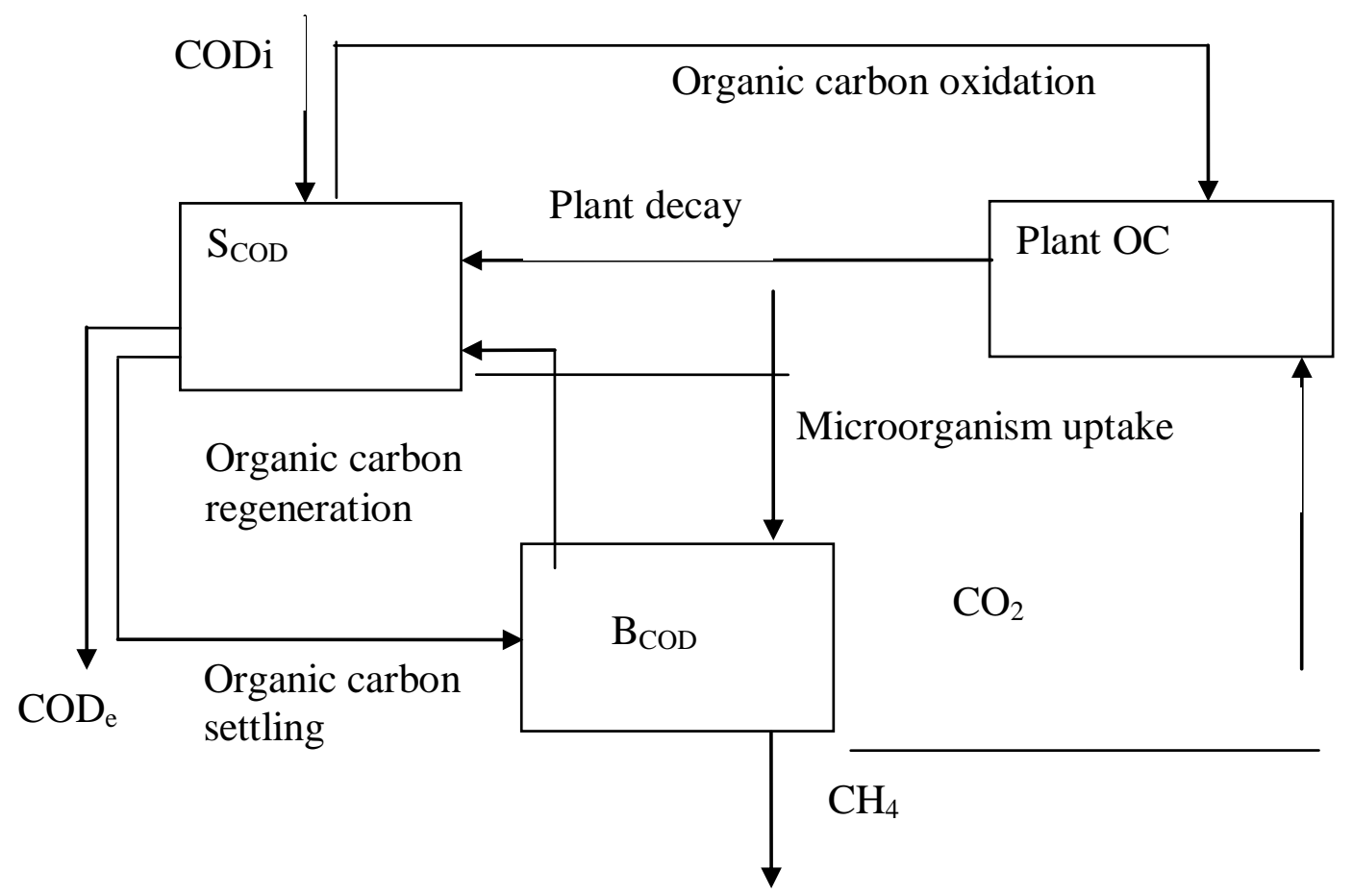

Figure 3. Conceptual model for organic matter transformation in wetland.

state variables substrate $\mathrm{COD}\left(\mathrm{S}_{\mathrm{COD}}\right)$, plant organic carbon (plant $\mathrm{OC}$ ) and $\mathrm{COD}$ in benthic layer $\left(\mathrm{B}_{\mathrm{COD}}\right)$, respectively.

The system was considered as a continuous plug flow hydraulic regime. The rate of change of COD concentration with time $\frac{d C}{d t}$ in wetland was based on the design assumption of the plug flow hydrodynamics and the first-order organic matter removal kinetics (USEPA, 1988) as shown in Equation (2).

$$
\frac{d C}{d t}=-k_{T} t
$$

In which $\mathrm{t}=$ hydraulic retention time $\left(\right.$ day $\left.^{-1}\right)$; and $\mathrm{k}_{\mathrm{T}}$ is temperature-dependent first-order reaction rate constant at wastewater temperature of $\mathrm{T}^{\circ} \mathrm{C}$, which is given as

$$
k_{T}=k_{20} \theta^{(T-20)}
$$

Where $\mathrm{k}_{20}=$ Reaction rate constant at $20^{\circ} \mathrm{C}$ and $\theta=$ Temperature coefficient. Equation (3) is obtained on integrating Equation (2).

$$
C_{\text {eff }}=C_{\mathrm{inf}} e^{-k_{T} t}
$$

Where $\mathrm{C}_{\text {eff }}$ and $\mathrm{C}_{\text {inf }}$ are concentrations of COD in effluent in $\mathrm{mg} \mathrm{I}^{-1}$ and influent in $\mathrm{mg} \mathrm{I}^{-1}$, respectively.
In analyzing the main influential mathematical expressions, mass balance equations of all organic materials were developed. The entire material balance that encompasses all forms of substances produced and consumed in biochemical processes, accumulations, inflows and outflows were considered. In this model, a steady state system was assumed. Equation (4) defines the overall mass balance equation for transformation and removal of organic carbon within the boundary of the water hyacinth constructed wetlands.

$\left(\frac{d O C}{d t}=C O D_{\text {inf }}-K_{o x}+K_{r e g c o D}+K_{d e c}-K_{u p}-K_{s d}-C O D_{e f f}\right)$

Where $\mathrm{dOC} / \mathrm{dt}=$ Rate of change of organic carbon concentration $\left(\mathrm{g} \mathrm{m}^{-2}\right.$ day $\left.^{-1}\right) ; \mathrm{K}_{\mathrm{up}}=$ Uptake rate of organic carbon by heterotrophic bacteria $\left(\mathrm{g} \mathrm{m}^{-2}\right.$ day $\left.^{-1}\right) ; \mathrm{K}_{\mathrm{ox}}=$ Organic carbon oxidized to carbon dioxide $\left(\mathrm{g} \mathrm{m}^{-2}\right.$ day $\left.^{-1}\right)$; $\mathrm{K}_{\text {reg } \mathrm{COD}}=$ Organic carbon regenerated from the sediment $\left(\mathrm{g} \mathrm{m}^{-2}\right.$ day $\left.^{-1}\right) ; \mathrm{K}_{\mathrm{sd}}=$ Sedimentation rate of particulate organic carbon settling $\left(\mathrm{g} \mathrm{m}^{-2}\right.$ day $\left.^{-1}\right) ; \mathrm{K}_{\mathrm{dec}}=$ Plant decay rate $\left(\mathrm{g} \mathrm{m}^{-2}\right.$ day $\left.^{-1}\right) ; \mathrm{COD}_{\text {inf }}=$ Chemical oxygen demand load in influent $\left(\mathrm{g} \mathrm{m}^{-2}\right.$ day $\left.^{-1}\right)$; COD eff $=$ Chemical oxygen demand load in the effluent $\left(\mathrm{g} \mathrm{m}^{-2}\right.$ day $\left.^{-1}\right)$.

The oxidation term $\left(\mathrm{K}_{\mathrm{ox}}\right)$ in Equation (4) is the amount of organic carbon oxidized to $\mathrm{CO}_{2}\left(\right.$ day $\left.^{-1}\right)$ by heterotrophic bacteria and is influenced by the concentration of dissolved oxygen and temperature in accordance with Equation (5). 


$$
K_{o x}=\left[\left(k_{20}+k_{b}\right) \cdot\left(\theta^{(T-20)} \cdot\left(\frac{D O}{K_{D O}+D O}\right)\right)\right] S_{C O D}
$$

Where $\mathrm{K}_{\mathrm{ox}}=$ Oxidation term $\left(\mathrm{g} \mathrm{m}^{-2} \mathrm{day}^{-1}\right) ; \mathrm{k}_{20}=$ First order reaction rate constant $\left(\right.$ day $\left.^{-1}\right) ; k_{b}=$ Biofilm constant (day $\left.{ }^{1}\right) ; \theta=$ temperature coefficient; DO = Dissolved oxygen concentration $\left(\mathrm{g} \mathrm{m}^{-3}\right) ; \mathrm{K}_{\mathrm{DO}}=$ Half saturation rate constant for dissolved oxygen concentration $\left(\mathrm{g} \mathrm{m}^{-3}\right) ; \mathrm{B}_{\mathrm{COD}}=\mathrm{COD}$ concentration $\left(\mathrm{g} \mathrm{m}^{-2}\right)$.

The substrate consumption rate by the biofilm bacteria $\mathrm{K}_{\mathrm{sb}}$ is defined by Equation (6).

$$
K_{s b}=k_{b} C_{t}
$$

Where $C_{t}=$ Substrate concentration at time $t\left(\mathrm{~g} \mathrm{~m}^{-2}\right)$. Biofilm constant $k_{b}$ was modelled using Equation (7) in accordance with Polprasert and Agarwalla (1994).

$$
k_{b}=a_{s}\left(\frac{\alpha \lambda}{\alpha+\lambda}\right)
$$

$a_{s}$ is specific area for biofilm activity $\left(\mathrm{m}^{2} \mathrm{~m}^{-3}\right)$ which is calculated from the sum of the surface area of the bottom, sidewalls of the wetland and the roots of the plants in accordance with Equation (8).

$a_{s}=\frac{1}{h}+\frac{2}{W}+\frac{2}{l}+\frac{R_{S}}{h}$

The term $\alpha\left(\mathrm{m} \mathrm{day}^{-1}\right)$ in Equation (7) is defined by Equation (9).

$$
\alpha=\frac{D_{s}}{L_{S}}
$$

Where $D_{s}=$ Diffusivity of the substrate through the liquid $\left(\mathrm{m}^{2}\right.$ day $\left.^{-1}\right) ; L_{s}=$ the liquid sub-layer thickness $(\mathrm{m})$. The liquid sub-layer thickness $L_{s}$ was considered by Williamson and McCarty (1976) to consist of two layers, namely: $L_{o}$ the outer liquid sub-layer and $L_{b}$ the inner layer. The inner layer is considered constant with a dimension of $56 \mu \mathrm{m}$. Experiments on column reactor conducted by Rittmann and McCarty (1980) revealed that the liquid sub-layer thickness $\left(L_{s}\right)$ ranged from $1.198 \times 10^{-4}$ to $2.26 \times 10^{-4} \mathrm{~m}$ for superficial flow velocities between 3.22 and $43 \mathrm{~m} \mathrm{day}^{-1}$.

Coefficient $\lambda$ in Equation (7) is mathematically defined by Equation (10).

$$
\lambda=\tanh (\phi) K_{f a} \frac{L_{f}}{\phi}
$$

Where $\mathrm{K}_{\mathrm{fa}}=$ First order biofilm rate constant $\left(\mathrm{day}^{-1}\right) ; \mathrm{L}_{f}=$ Biofilm thickness $(\mathrm{m})$ which range from $1.462 \times 10^{-4}$ to $1.615 \times 10^{-4}$ in water hyacinth wetlands (Polprasert and Agarwalla, 1994). The characteristic biofilm parameter $(\phi)$ is defined by Equation (11).

$$
\phi=\sqrt{\left(\frac{k_{f a} L_{f}^{2}}{D_{f}}\right)}
$$

The uptake rate of organic carbon by heterotrophic bacteria in Equation (4) is influenced by forcing functions such as dissolved oxygen, quality of substrate, temperature and $\mathrm{pH}$ within the system of growth. The uptake rate of organic carbon by heterotrophic bacteria in $\mathrm{g} \mathrm{m}^{-2}$ day $^{-1}$ is given by Equation (12).

$$
K_{u p}=\frac{S_{C O D}}{Y_{\max }}\left[\mu_{\max }\left(\frac{S_{C O D}}{K_{S C O D}+S_{C O D}}\right)\left(\frac{D O}{K_{D O}+D O}\right)\left(\frac{K_{p H}}{K_{p H}-\left[10^{\left(p H_{o p}-p H\right)}-1\right]}\right) \theta^{(T-20)}\right] .
$$

Where $\mu_{\max }=$ Maximum growth rate of heterotrophic bacteria $\left(\right.$ day $\left.^{-1}\right) ; Y_{\max }=$ Maximum substrate utilization rate ( $\mathrm{mg}$ biomass $/ \mathrm{mg} \mathrm{COD}$ ); $\mathrm{K}_{\mathrm{pH}}=$ Limiting value for $\mathrm{pH} ; \mathrm{pH}_{\mathrm{opt}}$ = Optimum $\mathrm{pH} ; \mathrm{K}_{\mathrm{SCOD}}=$ Half rate saturation constant for COD concentration $\left(\mathrm{g} \mathrm{m}^{-2}\right) ; \mathrm{S}_{\mathrm{COD}}=\mathrm{COD}$ concentration $(\mathrm{g}$ $\left.\mathrm{m}^{-2}\right)$.

The decay of plants $\mathrm{K}_{\mathrm{dec}}$ depends on the uptake of inorganic carbon and mortality of the plants. Plant decaying rate is modeled using first-order kinetics in accordance with Equation (13).

$$
K_{\text {dec }}=P_{O C} D_{\text {rate }}
$$

Where $\mathrm{K}_{\mathrm{dec}}=$ Plants decay rate $\left(\mathrm{g} \mathrm{m}^{-2}\right.$ day $\left.^{-1}\right) ; \mathrm{P}_{\mathrm{OC}}=$ Uptake of organic carbon by plants $\left(\mathrm{g} \mathrm{m}^{-2}\right) ; D_{\text {rate }}=$ Plant decay constant $\left(\right.$ day $\left.^{-1}\right)$.

The sedimentation term $\mathrm{K}_{\mathrm{sd}}\left(\mathrm{g} \mathrm{m}^{-2}\right.$ day $\left.^{-1}\right)$ is considered to be the sum of sedimentation in the root zone $\left(\mathrm{S}_{\text {root }}\right)$ and plain sedimentation in the liquid zone $\left(S_{w}\right)$ and is represented by Equation (14).

$$
K_{s d}=S_{\text {root }}+S_{w}
$$

Sedimentation in the root zone $\left(S_{\text {root }}\right)$ is defined by Equation (15). The reaction rate coefficient is based on the cylindrical collector (Logan et al., 1993) because the root of the water hyacinth plants is assumed cylindrical.

$$
S_{\text {root }}=\frac{4}{\pi} \eta \frac{\alpha u_{f}(1-p)}{d_{c}}
$$


The parameter $\eta$ is a single collector removal efficiency calculated from Stokes' law in accordance with O'Melia (1985) and is defined by Equation (16).

$$
\eta=\frac{\left(\rho_{p}-\rho_{w}\right) g d_{p}^{2}}{18 \mu_{T}}
$$

Where $\mathrm{g}=$ Acceleration due to gravity $\left(\mathrm{m} \mathrm{s}^{-2}\right) ; \rho_{\mathrm{p}}=$ Density of particle $\left(\mathrm{kg} \mathrm{m}^{-3}\right) ; \rho_{\mathrm{w}}=$ Density of water $\left(\mathrm{kg} \mathrm{m}^{-3}\right)$; $\mathrm{d}_{\mathrm{p}}=$ Diameter of settling particle $(\mathrm{m})$ which ranges from 0.5 to $40 \mu \mathrm{m}$ (Metcalf and Eddy, 1995); $\alpha=$ Sticking coefficient of the particle which ranges from 0.0008 to 0.012 (Khatiwada and Polprasert, 1999); $u_{f}=Q / A=$ Flow velocity of the liquid $\left(\mathrm{m} \mathrm{s}^{-2}\right)$, where $Q$ and $A$ are flow rate and surface area; $P=$ Porosity of the media in percentage, which varies from 95 to $96.5 \%$ (Kim and Kim, 2000); $D_{\mathrm{co}}=$ Diameter of collector $(\mathrm{m})$ which ranges from 0.0006 to 0.003 (Reddy, 1985).

For temperature above $20^{\circ} \mathrm{C}$ the viscosity of water $(\mu)$ varies with temperature in accordance with Equation (17) (Weast, 1981).

$$
\log \frac{\mu_{T}}{\mu_{20}}=\left(\frac{1.3220(20-T)-0.0010539(T-20)^{2}}{T+105}\right)
$$

Where $\mu_{\mathrm{T}}=$ Viscosity of water at $\mathrm{T}^{\circ} \mathrm{C}\left(\mathrm{kg} \mathrm{m}^{-1} \mathrm{~s}^{-1}\right) ; \mu_{20}=$ Viscosity of water at $20^{\circ} \mathrm{C}=1.002 \times 10^{-3}\left(\mathrm{~kg} \mathrm{~m}^{-1} \mathrm{~s}^{-1}\right)$

Plain settling in the liquid zone follows Stoke's law in accordance with Equation (18).

$$
S_{w}=\left(\frac{\rho_{p}-\rho_{w}}{18 \mu}\right) g d_{p}^{2}
$$

The total sedimentation term $\left(\mathrm{K}_{\mathrm{sd}}\right)$ in the wetland unit is then defined by Equation (19).

$$
K_{s d}=\left[\frac{4}{\pi}\left(\frac{\rho_{p}-\rho_{w}}{18 * \mu}\right) g d^{2}{ }_{p} u_{f}\left(\frac{1-P}{D_{C O}}\right)+\left(\frac{\rho_{p}-\rho_{w}}{18 * \mu}\right) g d^{2}{ }_{p}\right] S_{C O D}-(19)
$$

The mass balance for $\mathrm{COD}_{\text {sink }}$ term $\left(\mathrm{g} \mathrm{m}^{-2}\right)$ is represented by Equation (20).

$$
\frac{d \operatorname{Sink}_{C O D}}{d t}=K_{u p}+K_{s d}-K_{r_{\text {eg }} O D}-K_{C O_{2}}-K_{C H_{4}}
$$

The rate of methane generation $\left(\mathrm{K}_{\mathrm{CH} 4}\right)$ is influenced by anaerobic condition in the COD sink. The generation rate of methane is modelled using first order kinetics in accordance with Equation (21).

$$
K_{C_{4}}=D_{m} \operatorname{Sink}_{B O D}
$$

Where $\mathrm{K}_{\mathrm{CH} 4}=$ Generation rate of methane $\left(\mathrm{g} \mathrm{m}^{-2}\right.$ day $\left.^{-1}\right)$; $\mathrm{COD}_{\text {sink }}=$ Sink COD term $\left(\mathrm{g} \mathrm{m}^{-2}\right) ; \mathrm{D}_{\mathrm{m}}=$ Generation constant for methane $\left(\mathrm{day}^{-1}\right) ; \mathrm{K}_{\mathrm{CO} 2}=$ Release rate of carbon (day ${ }^{-1}$ ) from the sediment in Equation (20), and is defined by Equation (22).

$$
K_{C O_{2}}=U_{r(20)} \beta^{(T-20)} S_{B O D} * 0.531 S_{b}
$$

Where $U_{\mathrm{r}(20)}=$ Release rate $\left(\right.$ day $\left.^{-1}\right) ; \beta=$ Arrhenius temperature constant; $\mathrm{COD}_{\text {sink }}=$ Active bacterial biomass $\left(\mathrm{g} \mathrm{m}^{-2}\right) ; \mathrm{S}_{\mathrm{b}}=$ Fraction of bacteria settling.

The mass balance for plant uptake rate of inorganic is defined by Equation (23).

$$
\frac{d P_{O C}}{d t}=K_{O X}+K_{C O_{2}}-K_{d e c}
$$

\section{Calibration and optimization of model parameters}

STELLA 6.0.1 software was used to run the developed conceptual model that incorporated equations of different processes involved in the wetland system. Mathematical processes were used to connect the various relationships among state variables and forcing function. Equations defining processes like sedimentation, biofilm activity and growth of microorganism, regeneration of organic carbon, decay of plant biomass and oxidation of organic carbon to carbon dioxide were included into the model. The data collected from the wetland units were used as inputs to the model for model calibration. The inputs were the influent concentration of COD, dissolved oxygen concentrations, $\mathrm{pH}$ and temperature values that were measured on daily basis. The simulation was done using Stella II software, which integrated the model using the in-built fourth-order Runge-Kutta approximation. The best values for unknown coefficient were obtained through calibration using observed data against simulated ones. The model efficiency $R^{2}$ was calculated from Nash and Sutcliffe (1970), which is given by Equation (24).

$R^{2}=\frac{F_{o}-F}{F}$

Where $F_{o}$ is the sum of the difference of squares between the observed and mean of observed values while $F$ is the sum of the difference of squares between the observed and computed values.

The conceptual diagram shown by Figure 3 was used for modeling the transformation of organic carbon in wetlands. The sensitivity analysis of model results against model inputs indicated the sensitive parameters as the maximum growth rate of microorganism bacteria $\left(\mu_{\text {max }}\right)$, temperature coefficient $(\theta)$, specific area for biofilm 
Table 2. Model calibration values.

\begin{tabular}{|c|c|c|c|c|}
\hline No. & Parameter & Literature range & Reference & Calibration \\
\hline 1. & Temperature coefficient $(\Theta)$ & 1.0 to 1.1 & Metcalf and Eddy (1995) & 1.02 \\
\hline 2. & Maximum growth rate of heterotrophic bacteria at $20^{\circ} \mathrm{C}, \mu_{\max \_20}$ & 0.18 & Ferrara and Hermann (1980) & 0.16 \\
\hline 3. & Optimum pH, $\mathrm{pH}_{\mathrm{opt}}$ & $4.0 \sim 9.5$ & Barnes et al. (1981) & 7.5 \\
\hline 4. & First order biofilm rate constant $\mathrm{K}_{\mathrm{fa}}\left(\right.$ day $\left.^{-1}\right)$ & 336.6 & Polprasert and Agarwalla (1994) & 336.6 \\
\hline 5. & Half rate saturation constant for $\mathrm{DO}, \mathrm{K}_{\mathrm{DO}}\left(\mathrm{g} \mathrm{m}^{-3}\right)$ & $0.1 \sim 1.0$ & Okabe et al. (1995) & 1.0 \\
\hline 6. & Sticking coefficient, a & $0.0008 \sim 0.012$ & Polprasert and Khatiwada (1999) & 0.008 \\
\hline 9. & Liquid layer thickness, Ls (m) & $1.19 \times 10^{-4} \sim 2.26 \times 10^{-4}$ & Ritmann and McCarty (1980) & $2.26 \times 10^{-4}$ \\
\hline 10. & Biofilm thickness, $\mathrm{Lf}_{\mathrm{f}}(\mathrm{m})$ & $1.462 \times 10^{-4} \sim 1.615 \times 10^{-4}$ & Polprasert and Agarwalla (1994) & $1.615 \times 10^{-3}$ \\
\hline 11. & Half rate saturation constant for $\mathrm{COD}, \mathrm{K}_{\mathrm{scOD}}\left(\mathrm{g} \mathrm{m}^{-3}\right)$ & 15 to 75 & Okabe et al. (1995) & 18 \\
\hline 12. & Density of settling particle, $\rho_{p}\left(\mathrm{~kg} \mathrm{~m}^{-3}\right)$ & 1050 to 1500 & Metcalf and Eddy (1995) & 1300 \\
\hline 13. & Fraction of bacteria settling, $S_{b}$ & 0.05 & Canale (1976) & 0.05 \\
\hline 17. & Viscosity of water, $\mu_{20}\left(\mathrm{~kg} \mathrm{~m}^{-1} \mathrm{~s}^{-1}\right)$ & $1.002 \times 10^{-3}$ & Metcalf and Eddy (1995) & $1.002 \times 10^{-3}$ \\
\hline 18. & Diffusivity of a substrate in biofilm layer, $D_{f}\left(m^{2}\right.$ day $\left.^{-1}\right)$ & $2.3 \times 10^{-5}$ & Rittman and McCarty (1980) & $2.38 \times 10^{-5}$ \\
\hline 19. & Diameter of collector, $\mathrm{D}_{\mathrm{co}}(\mathrm{m})$ & $0.0006 \sim 0.003$ & Reddy (1985) & 0.0007 \\
\hline 20. & Regeneration rate for inorganic carbon, $U_{\mathrm{r}}\left(\right.$ day $\left.^{-1}\right)$ & 0.09 & Foree and Jewell (1970) & 0.07 \\
\hline 21. & Arrhenius temperature constant at $20^{\circ} \mathrm{C}, \mathrm{B}$ & $1.02 \sim 1.09$ & Fritz et al. (1979) & 1.04 \\
\hline 22. & Porosity, P (\%) & $95 \sim 96.5$ & Kim and Kim (2000) & 96 \\
\hline 23. & Generation constant for Methane, $D_{m}\left(\right.$ day $\left.^{-1}\right)$ & - & - & 0.006 \\
\hline 24. & Settling particle diameter, $d_{p}(\mu m)$ & $0.5 \sim 40$ & Metcalf and Eddy (1995) & $5.6 \mu \mathrm{m}$ \\
\hline
\end{tabular}

activity $\left(a_{s}\right)$, settling particle diameter $\left(d_{p}\right)$, first order reaction rate constant $\left(\mathrm{k}_{20}\right)$, half rate saturation constant for COD concentration $\left(\mathrm{K}_{\mathrm{COD}}\right)$, density of settling particle $\left(\rho_{p}\right)$ and maximum substrate utilization $\left(Y_{\max }\right)$.

The main objective of the simulation was to predict the effect of the activities of suspended biomass and attached plant root biofilm, on transformation and removal mechanisms of organic carbon in water hyacinths constructed wetlands. The efficiency of the model was found to be $73 \%$, which indicates that the observed data fits well with the simulated values. The values of the optimized constants and coefficients used in the model during calibration are shown in Table 2.

The system performance showed the mean observed COD effluent was $110.5 \mathrm{~g} \mathrm{~m}^{-2}$ while the computed effluent was $104.4 \mathrm{~g} \mathrm{~m}^{-2}$. The Mean Absolute Deviations (MAD), which is the average deviations between each data value and the mean, was determined from 25 data sets collected over a two month period. MAD of the observed and the computed effluent were 16.4 and $19.4 \mathrm{~g} \mathrm{~m}^{-2}$, respectively and the observed and simulated removal percentages of COD in the unit were 38.3 and $40.5 \%$, respectively. The closeness of these values suggests that the model predicted well the organic carbon transformation mechanisms in water hyacinth constructed wetlands. Table 3 shows the COD mass balance for state variables simulated by the model. The state variables were substrate COD, plant organic carbon and sink COD. The processes involved in transformation mechanisms were oxidation of organic carbon to carbon dioxide, plant decay, regeneration of organic carbon, uptake of organic carbon by heterotrophic bacteria, settling of organic carbon and generation of methane.

The overall mass balance was $69.2 \mathrm{~g} \mathrm{~m}^{-2}$ day $^{-1}$ which is close to $67.1 \mathrm{~g} \mathrm{~m}^{-2}$ day ${ }^{-1}$, which is the total sum of the accumulation in plant OC, sink ${ }_{C O D}$, and $S_{C O D}$ in the system. This shows that the system obey the law of mass conservation. About $7.5 \mathrm{~g} \mathrm{~m}^{-2} \mathrm{day}^{-1}$ of carbon dioxide was consumed by plants in the photosynthesis process (the oxidation process contributed $6.4 \%$ ) while the decay process returned $6.7 \mathrm{gm}^{-2}$ day $^{-1}$ to the water body (contribution to the transformation process was 4.4\%) Thus, an accumulation of $0.95 \mathrm{~g} \mathrm{~m}^{-2}$ day $^{-1}$ organic carbon in the plant biomass was observed which is completely removed from the system. About $17.9 \mathrm{~g} \mathrm{~m}^{-2}$ day $^{-1}$ of organic carbon was consumed by microorganism in the formation of new cellular material (contribution to the transformation was $4.2 \%)$. The uptake of organic carbon by microorganism resulted to the regeneration of $53.1 \mathrm{~g}$ $\mathrm{m}^{-2}$ day $^{-1}$ of organic carbon back to water column (this transformation process accounted only $25.5 \%$ ). About $106.4 \mathrm{~g} \mathrm{~m}^{-2}$ day $^{-1}$ of organic carbon was settled down to the sediment leading to high removal of $56.5 \%$ from the system. Therefore, due to sludge accumulation anaerobic 
Table 3. Transformation mechanisms of organic material in Water hyacinth wetland.

\begin{tabular}{clc}
\hline No. & Transformation process & Mass load of organic material $\left(\mathbf{g ~ m}^{-2}\right.$ day $\left.^{-1}\right)$ \\
\hline 1. & Influent organic material & 175.5 \\
2. & Effluent organic material & 104.4 \\
3. & Organic material settled in the benthic layer & 106.4 \\
4. & Organic material regenerated from the benthic layer & 53.1 \\
5. & Methane released from the benthic layer & 3.8 \\
6. & Water hyacinth decay rate & 6.7 \\
7. & Organic material oxidized by heterotrophic bacteria & 7.4 \\
8. & Uptake of organic material by microorganisms & 17.9 \\
9. & Oxidative catabolism of organic material to $\mathrm{CO}_{2}$ & 2.7 \\
\hline
\end{tabular}

decomposition in the sediment released $2.7 \mathrm{~g} \mathrm{~m}^{-2}$ day $^{-1}$ of $\mathrm{CO}_{2}$ to the system and $3.8 \mathrm{~g} \mathrm{~m}^{-2}$ day ${ }^{-1}$ of $\mathrm{CH}_{4}$ was completely removed from the system $\left(\mathrm{CO}_{2}\right.$ and $\mathrm{CH}_{4}$ contributed 1.2 and $1.8 \%$ to the transformation process). The permanent COD removal was $26.7 \%$ and largely contributed by sedimentation, biofilm activity and to smaller extent by generation of methane.

The effects of biofilm biomass activities were studied by setting the biofilm parameter to zero in the calibrated model and re-run. The output produced the removal percentage of COD was $34.0 \%$ when the model was simulated without considering the effect of biofilm, which is lower than $40.5 \%$ when biofilm effect was taken into consideration. The mean absolute deviation (MAD) of simulated effluents with and without biofilm effect was 10.0 and $34.5 \mathrm{~g} \mathrm{~m}^{-2}$, respectively. This high divergence showed the significance of the biofilm effect in transformation and removal of organic carbon through bio-oxidation mechanism as studied by Sooknar (2000). These results confirm the results of Stowell et al. (1981) who reported that water hyacinth roots provide physical support for a thick bacteria biofilm that actively degrades the organic matter.

\section{Model applications and limitations}

This mathematical model can be used to predict transformation and removal of organic material in artificial wetlands implanted with $E$. crassipes. Its applications require knowledge of influent concentration of organic material, effective surface area of $E$. crassipes roots, flow rates of domestic wastewater, density and size of settling particle, porosity of the media and biofilm activities. Other environmental and physical-chemical parameters required include $\mathrm{pH}$, temperature and dissolved oxygen. Stella 6.0.1 software or any other software may be used to simulate any state variable or process provided all inputs are known.

\section{Conclusions}

From the results of this study the following conclusions are made:

(1) Transformation of organic material in E. crassipes artificial wetland was governed by settling of organic solids to benthic layer $\left(104.4 \mathrm{~g} \mathrm{~m}^{-2}\right.$ day $\left.^{-1}\right)$, regeneration of soluble organic matter from particulate matter $\left(53.1 \mathrm{~g} \mathrm{~m}^{-}\right.$ ${ }^{2}$ day $^{-1}$ ) and uptake of organic matter by microorganisms $\left(17.9 \mathrm{~g} \mathrm{~m}^{-2}\right.$ day $\left.^{-1}\right)$ and uptake by organic material by biofilm growth on $E$. crassipes $\left(7.4 \mathrm{~g} \mathrm{~m}^{-2}\right.$ day $\left.^{-1}\right)$. Other transformation route such as decay of E. crassipes $(6.7 \mathrm{~g}$ $\mathrm{m}^{-2}$ day $\left.^{-1}\right)$ and release of gases such as methane $\left(3.8 \mathrm{~g} \mathrm{~m}^{-}\right.$ ${ }^{2}$ day $\left.^{-1}\right)$ and carbon-dioxide $\left(2.7 \mathrm{~g} \mathrm{~m}^{-2}\right.$ day $\left.^{-1}\right)$ from benthic layer were relatively ineffective.

(2) Organic material was largely removed through net loss to sediments $\left(64.7 \mathrm{~g} \mathrm{~m}^{-2} \mathrm{day}^{-1}\right)$, production of methane from benthic layer $\left(3.8 \mathrm{~g} \mathrm{~m}^{-2}\right.$ day $\left.^{-1}\right)$ and net carbon removed through uptake by plants and microorganisms $\left(3.4 \mathrm{~g} \mathrm{~m}^{-2} \mathrm{day}^{-1}\right)$. The total mass of removed carbon amounted to $71.9 \mathrm{~g} \mathrm{~m}^{-2}$ day $^{-1}$, which is equivalent to $41 \%$ efficiency of organic carbon removal in this wetland.

\section{Conflict of Interests}

The author(s) have not declared any conflict of interests.

\section{REFERENCES}

Barnes D, Bliss PJ, Gould BW, Valentine HR (1981). Water and Wastewater Engineering Systems. Pitman Books Limited London.

Barrie A (2002). Modelling COD removal in water hyacinths constructed wetland. MSc Dissertation, Department Water Resources Engineering, University of Dar es Salaam, Tanzania.

Bigambo T, Mayo AW (2005). Nitrogen transformation in horizontal subsurface flow constructed wetlands II: Effect of biofilm. J. Phys. Chem. Earth 30:668-672.

Canale RP (1976). Modelling biochemical processes in aquatic ecosystems. Ann Arbor Science Pub. Co, Ann Arbor, Michigan.

Ferrara RA, Hermann DPF (1980). Dynamic Nutrient Cycle Model for Waste Stabilization Ponds. J. Environ. Eng. Div. Am. Soc. Civ. Eng. 106(1):37-55.

Foree EG, Jewell WJ (1970). The extent of nitrogen and phosphorus regeneration from decomposing algae. In: Advances in Water Pollution Research. Proceedings of the $5^{\text {th }}$ International Conference on Water Research. Pergamon Press Ltd., London. New Zealand J. 
Mar. Freshw. Res. 14(2):121-128.

Fritz JJ, Middleton AC, Meredith DD (1979). Dynamic Process Modelling of Wastewater Stabilization Ponds. J. Water Pollut. Control Fed. 51(11):2724-2742.

Gersberg RM, Elkins SR, Lyons A, Godman CR (1985). Role of aquatic plants in wastewater treatment by artificial wetlands. Water Res. 20:363-368.

Kalibbala M, Mayo AW, Asaeda T, Shilla DA (2008). Modelling faecal streptococci mortality in constructed wetlands implanted with Eichhornia crassipes. Wetland Ecol. Manage. 16:499-510.

Khatiwada NR, Polprasert C (1999). Kinetics of fecal coliform removal in constructed wetlands. Water Sci. Technol. 40(3):109-116.

Kim Y, Kim WJ (2000). Roles of water hyacinth and their roots for reducing algal concentration in the effluent for waste stabilization ponds. Water Res. 34(13):3285-3294.

Knight LR, Clarke AR, Bastian KR (2000). Treatment Wetlands as Habitat for Wildlife and Humans. $7^{\text {th }}$ International Conference on Wetland Systems for Water Pollut. Control (1):37.

Logan BE, Hilbert TAA, Anold RG (1993). Removal of bacteria in laboratory filters: Models and experiments. Water Res. 27(6):955962.

Mashauri DA, Kayombo S (2002). Application of the two Coupled Models for Water Quality Management: Facultative pond cum Constructed Wetland Models. J. Phys. Chem. Earth 27:773-781.

Mayo AW (1989). Effect of the pond depth on bacteria mortality rate, J. Environ. Eng. Div. Am. Soc. Civ. Eng. 115(5):964-977.

Mayo AW, Muraza M, Norbert J (2013). The Role of Mara River Basin Wetland in Reduction of Nitrogen Load to Lake Victoria. Int. J. Water Resour. Environ. Eng. 5(12):659-669.

Mayo AW, Bigambo T (2005). Nitrogen transformation in horizontal subsurface flow constructed wetlands I: Model development. J. Phys. Chem. Earth 30:658-667.

Mayo AW, Kalibbala M (2007). Modelling faecal coliform mortality in water hyacinths ponds. J. Phys. Chem. Earth 32:1212-1220.

Metcalf and Eddy Inc. (1995). Wastewater Engineering: Treatment, Disposal and Reuse. $3^{\text {rd }}$ McGraw-Hill Ltd. New Delhi, pp. 82-1204.

Mugasha AL (1995). A study of the potential use of water hyacinth, Eichhornia crassipes (Mart.) Solms., in the control of chromium and lead pollution in fresh waters. MSc. Thesis, University of Dar es Salaam.

Muyodi FJ (2000). Microbiological analysis of the waters of Lake Victoria in relation to the invasion of the water hyacinth Eichhornia crassipes (Mart.) Solms.: A case study of the lakeshores of Mwanza Municipality. Ph.D Thesis, University of Dar es Salaam.

Nakibuule J (2013). The transformation and removal of nitrogen in horizontal sub-surface flow constructed wetlands. Final Year Project, Department of Water Resources Engineering, University of Dar es Salaam.

Nash JE, Sutcliffe JV (1970). River flow forecasting through conceptual models. J. Hydrol., 10:282-290.

Okabe S, Hirata K, Watanabe Y (1995). Dynamic changes in spatial microbial distribution in mixed population biofilm, experimental and model simulation. Water Sci. Technol. 32(8):67-74.

Okurut D (2013). Biofilm Effects on Nitrogen Transformation and Removal in Subsurface Flow Constructed Wetlands planted with Typha Domingensis. MSc Dissertation, Department of Water Resources Engineering, University of Dar es Salaam.

O'Melia CR (1985). Particles, pretreatment and performance in water filtration. J. Environ. Eng. Div. Am. Soc. Civ. Eng. 116(6):874-905.

Polprasert C, Agarwalla BK (1994). A Facultative Pond Incorporating Biofilm activity. Water Environ. Res. 66(5):725-732.

Polprasert C, Khatiwada NR (1997). Role of Biofilm Activity in Water Hyacinths Pond Design and Operation. Proceedings of Asian Water Quality 97, $6^{\text {th }}$ IAWQ Asian-Pacific Regional Conference, Int. Association on Water Quality and Korean SOC of Water Quality. Seoul, Korea.
Reddy KR (1985). Nutrient transformations in aquatic macrophyte filters used for water purification. Purification Water Reuse 111, American Water Works Association, Denver, Colorado, pp. 660-678.

Reed SC, Crites RW, Middlebrooks EJ (1995). Natural systems for waste Management and Treatment. McGraw-Hill Book Co., New York, NY, pp. 225-262.

Rittmann BE, McCarty PL (1980). Evaluation of Steady State Biofilm Kinetics. Biotechnol. Bioeng. 22:2343-2359.

Senzia MA (2003). Modelling of nitrogen transformation and removal in subsurface flow constructed wetlands during treatment of domestic wastewater. PhD Thesis, Department Water Resources Engineering, University of Dar es Salaam, Tanzania.

Senzia AM, Mashauri DA, Mayo AW (2004). Modelling Nitrogen Transformation in Horizontal Subsurface flow Constructed Wetlands Planted with Phragmites mauritianus. J. Civ. Eng. Res. Pract. 1(2):115.

Sooknar $R$ (2000). A review of the mechanisms of pollutant removal in water hyacinth systems. Sci. Technol. Res. J. Univ. Mauritius, Reduit, Mauritius 6:50-56.

Standard Methods for the Examination of Water and Wastewater (2012). American Public Health Association, American Water Works Associations, Water Pollution Control Federal $-22^{\text {nd }}$ Edition, Washington, DC.

Stowell R, Ludwig R, Colt J, Tchobanoglous T (1981). Concepts in aquatic treatment design. J. Environ. Eng. Div. Am. Soc. Civ. Eng 112:885-894.

U.S Environmental Protection Agency (1988). Design Manual. Constructed Wetlands and Aquatic plant Systems for Municipal Waste Treatment. EPA/625/1-88/002, Cincinnati, OH 45268, pp. 2 53.

Vymazal J (2010). Constructed wetlands for wastewater treatment. Water 2:503-549.

Water 21 (2000). Constructed wetlands: A global technology. Magazines of International Water Association, June, pp. 57-58.

Weast RC (1981). Handbook of Chemistry and Physics $61^{\text {st }}$ Ed. CRC Press, Boca Raton, Florida.

Williamson KJ, McCarty PL (1976). A Model of Substrate Utilization by Bacteria Films. J. Water Pollut. Control Fed. 48(1):9-24.

Yi Q, Hur C, Kim Y (2009). Modelling nitrogen removal in water hyacinth ponds receiving effluent from waste stabilization ponds. Ecol. Eng. 35(1):75-84. 